JURNAL NOMINAL / VOLUME VII NOMOR 2 / TAHUN 2018

\title{
PENGEMBANGAN APLIKASI MIKURO BERBASIS ANDROID SEBAGAI MEDIA PENYUSUNAN LAPORAN KEUANGAN UNTUK USAHA JASA
}

\section{DEVELOPMENT “MIKURO” BASED ON ANDROID AS MEDIA OF FINANCIAL STATMENT PREPARATION FOR SERVICES BUSINESS}

\author{
Susanti \\ Prodi Akuntansi Universitas Negeri Yogyakarta \\ Shanty639@gmail.com \\ Endra Murti Sagoro, S.E., M.Sc. \\ Staf Pengajar Program Studi Akuntansi Universitas Negeri Yogyakarta
}

\begin{abstract}
Abstrak : Pengembangan Aplikasi Mikuro Berbasis Android Sebagai Media Penyusunan Laporan Keuangan Untuk Usaha Jasa. Tujuan dari penelitian ini adalah untuk mengembangkan aplikasi "Mikuro" berbasis android sebagai media penyusunan laporan keuangan untuk usaha mikro dengan jenis usaha jasa. Tujuan kedua adalah mengetahui kelayakan aplikasi "Mikuro" berbasis android. Penelitian ini merupakan penelitian dengan menggunakan model 4D yaitu Define, Design, Develop dan Disseminate. Subjek dalam penelitian ini adalah ahli media, ahli materi, serta 35 pelaku usaha di Yogyakarta. Objek dalam penelitian ini adalah aplikasi "Mikuro" berbasis android.Teknik pengumpulan data dalam penelitian ini melalui angket. Teknik analisis data yang digunakan yaitu analisis deskiptif kualitatif dan kuantitatif. Hasil penelitian ini yaitu : 1) Aplikasi "Mikuro" ini melalui 4 tahapan dalam pengembangan yaitu Define atau tahap pendefinisian, Design atau tahap perancangan, Develop atau tahap pengembangan, dan Disseminate atau tahap penyebaran. 2) Berdasarkan penilaian ahli materi "Mikuro" dinyatakan Sangat Layak dengan skor rata-rata 4,39; 3) Berdasarkan penilaian dari Ahli media "Mikuro" dinyatakan Sangat Layak dengan skor rata-rata 4,4; dan 4) Penilaian dari pelaku usaha mengenai aplikasi "Mikuro" dinyatakan Layak dengan skor rata-rata 3,86 yang dapat dikategorikan Layak.
\end{abstract}

Kata kunci: Aplikasi "Mikuro", Android, Media Laporan Keuangan

\begin{abstract}
Development "Mikuro" Based On Android As Media Of Financial Statment Preparation For Services Business. The aims of this research is to develop "Mikuro" application based on android as media of preparation of financial report for micro business with service business type. The second aims is to know the feasibility of application "Mikuro" based on android.This research and development applied 4D model, that is Define, Design, Develop and Disseminate. subject in this reasearch were, media experts, material experts, and 35 business mans in Yogyakarta. Objects in this reasearch are applications "Mikuro" based on android. Data collection techniques in this study throught a questionnaire. Data obtained from the questionnaire and then analyzed descriptively qualitative and quantitative.The results of this study are: 1) Application "Mikuro" is through 4 stages in the development of Define, Design, Develop, and Disseminate. 2) Based on expert assessment of material "Mikuro" stated Totally Feasible with average score 4,39; 3) Based on the assessment of media experts "Mikuro" stated Totally Feasible with an average score of 4.4; and 4) Assessment of business actors regarding "Mikuro" application is declared Worthy with an average score of 3.86 which can be stated Feasible.
\end{abstract}

Keywords: "Mikuro", Android, Media Financial Report 


\section{JURNAL NOMINAL / VOLUME VII NOMOR 2 / TAHUN 2018}

\section{PENDAHULUAN}

Laporan keuangan adalah informasi yang sangat penting dalam suatu perusahaan. Laporan keuangan disajikan secara periodik untuk mengetahui kinerja suatu perusahaan. Hal tersebut selaras dengan yang dinyatakan oleh Raharjaputra (2011: 194), "laporan keuangan merupakan alat yang sangat penting untuk memperoleh informasi sehubungan dengan posisi keuangan dan hasil yang telah dicapai oleh perusahaan yang bersangkutan”. Keakuratan suatu laporan keuangan sangat dibutuhkan untuk pengambilan keputusan dan pengendalian pada perusahaan. Bukan hanya perusahaan besar saja yang membutuhkan lapran keuangan namun juga Usaha Mikro, Kecil dan Menengah. Menurut SAK EMKM (2018, 3), tujuan laporan keuangan adalah untuk menyediakan informasi posisi keuangan dan kinerja suatu entitas yang bermanfaat bagi sejumlah besar pengguna dalam pengambilan keputusan ekonomik oleh siapapun yang tidak dalam posisi dapat meminta laporan keuangan khusus untuk memenuhi kebutuhan informasi tersebut.

Laporan keuangan dibuat berdasarkan transaksi-transaksi yang terjadi di perusahaan selama periode tertentu. Transaksi-transaksi tersebut dicatat secara runtut berdasarkan waktu terjadinya transaksi. Sehingga akan menghasilkan laporan keuangan yang sesuai dengan kondisi yang sebenarnya terjadi di perusahaan. Menurut Hanafi dan Halim (2014: 12), "secara umum ada tiga bentuk laporan keuangan yang pokok yang dihasilkan oleh suatu perusahaan yaitu, neraca, laporan laba-rugi, dan laporan aliran kas". Pernyataan SAK EMKM bab 3 paragraf 9 menyebutkan bahwa laporan keuangan minimum terdiri dari laporan posisi keuangan pada akhir periode, laporan laba rugi selama periode, dan catatan atas laporan keuangan, yang berisi tambahan dan rincian akun-akun tertentu yang relevan.

Usaha Mikro Kecil Menengah mempunyai peranan penting di dalam pembangunan dan pertumbuhan ekonomi baik di negara berkembang maupun negara maju. UMKM di Indonesia berperan sebagai sumber pertumbuhan kesempatan kerja atau pendapatan. Fakta menunjukkan bahwa kesempatan kerja yang diciptakan oleh UMKM jauh lebih banyak dibandingkan tenaga kerja yang bisa diserap oleh usaha besar. Hal tersebut diperkuat dengan data BPS tahun 2016 jumlah tenaga kerja UKM sebanyak 53.641.524 sedangkan tenaga kerja kerja UB sebanyak 16.678.942. Dengan banyak menyerap tenaga kerja berarti UMKM juga memiliki peran dalam upaya pemerintah memerangi kemiskinan di Indonesia.

Badan Ekonomi Kreatif menyebutkan bahwa masih banyak Usaha Mikro Kecil dan Menengah yang belum mampu menyusun laporan keuangan. Dikutip dari 


\section{JURNAL NOMINAL / VOLUME VII NOMOR 2 / TAHUN 2018}

jogja.tribunnews.com, Kepala Sub Direktorat Perbankan Syariah Badan Ekonomi Kreatif (Bekraf) Yuke Sri Rahayu saat berada di Kantor Perwakilan Bank Indonesia DIY mengatakan, meski belum terdata secara pasti UMKM yang telah mampu menyusun laporan keuangan, setiap mereka menggelar pelatihan terhadap UMKM, hanya $20 \%$ yang mampu menyusunnya. Masih banyak UMKM yang belum membuat neraca, laporan keuangan, dan laba-rugi. Kurangnya pemahaman tentang akuntansi ataupun pelaporan keuangan menjadikan perkembangan UMKM berjalan lambat.

Kurangnya pemahaman tentang keuangan terutama dalam pelaporan, menimbulkan masalah baru yaitu pelaku UMKM kesulitan dalam akses perkreditan. Ribuan UMKM di Indonesia banyak yang dianggap kurang memenuhi persyaratan bank karena pelaku UMKM sendiri masih buta terhadap laporan keuangan. Sedangkan laporan keuangan ini sangat penting karena menjadi bukti apakah usaha tersebut sehat atau tidak. Selain itu, dari laporan keuangan tersebut pihak bank dapat memperkirakan berapa kredit yang akan diberikan kepada pelaku UMKM.

Pelaku UMKM saat ini masih belum mengetahui atau memahami manfaat dari laporan laba rugi, laporan posisi keuangan/neraca, laporan perubahan modal. Hal tersebut dikarenakan pelaku UMKM sendiri masih buta terhadap laporan keuangan. Menurut Setyorini, dkk (2012), “alasan pelaku UMKM tidak menggunakan akuntansi antara lain adalah akuntansi dianggap sesuatu yang sulit dan tidak penting. Beberapa pelaku UMKM mengatakan bahwa tanpa akuntansi pun perusahaan tetap berjalan lancar dan selalu memperoleh laba".

Dikutip dari Jogja.tribunnews.com (25/10/2017), Bekraf berusaha keras meningkatkan kemampuan dari pelaku usaha agar bisa menyusun laporan keuangan yang lebih baik sesuai dengan standar perbankan. Hal tersebut dimaksudkan agar meningkatkan kepercayaan perbankan untuk mengucurkan kredit pelaku usaha. Bekraf berusaha memberikan aplikasi laporan keuangan yang mudah dan bisa diterapkan pada UMKM. Saat ini Bekraf tengah gencar melakukan sosialisasi dan pendampingan penyusunan laporan keuangan kepada UMKM diantaranya dengan aplikasi keuangan berbasis syariah.

Perusahaan dapat memanfaatkan teknologi informasi untuk membuat laporan keuangan. Teknologi saat ini telah banyak berkembang. Perusahaan dapat menggunakan sistem komputerisasi yang telah diprogram dalam pembuatan laporan keuangan. Dengan perkembangan teknologi tersebut akan mempermudah perusahaan untuk menghindari atau meminimalisir terjadinya kesalahan dan keterlambatan pelaporan keuangan. 


\section{JURNAL NOMINAL / VOLUME VII NOMOR 2 / TAHUN 2018}

Perkembangan teknologi informasi dan komunikasi saat ini semakin pesat. Hal tersebut memudahkan untuk melakukan segala hal. Terutama dalam mengakses dan mengelola informasi, termasuk laporan keuangan. Dengan perkembangan teknologi saat ini banyak dilakukan pengembangan dalam menciptakan alat bantu dalam menjalankan aktifitas perusahaan. Dengan perkembangan zaman yang diikuti oleh perkembangan teknologi aktifitas perusahaan dapat dilakukan dengan mudah. Contohnya para online shop dengan menggunakan smartphone dapat melayani pembeli tanpa harus bertemu secara langsung.

Dikutip dari http://kominfo.com lembaga riset digital marketing Emarketer memperkirakan pada tahun 2018 jumlah pengguna aktif smartphone di Indonesia lebih dari 100 juta orang. Berdasarkan data tersebut menandakan bahwa Indonesia telah mengalami perkembangan yang sangat pesat dalam bidang teknologi mobile. Peningkatan penggunaan teknologi mobile terjadi karena hampir semua bidang memanfaatkan teknologi informasi tersebut.

Sejumlah perusahaan telah memanfaatkan teknologi mobile, misalnya Go-jek, GrabBike, dan situs-situs belanja online yang sekarang sangat banyak berkembang. Smartphone adalah telepon pintar yang kegunaanya tidak sebatas telepon, sms, game dan kamera saja, namun juga dapat dimanfaatkan lebih dari itu karena saat ini sudah banyak pengembangan-pengembangan aplikasi untuk memudahkan pengguna smartphone dalam berbagai kegiatan. Pelaku usaha kecil pun sudah banyak yang menggunakan smartphone. Smartphone ini dimanfaatkan oleh pengusaha kecil sebagai alat komunikasi. Adanya teknologi smartphone android akan membuat pengguna semakin dimudahkan dengan beragam aplikasi yang dikembangkan oleh para pengembang. Pelaku UMKM saat ini pun sudah banyak yang menggunakan smartphone berbasis android untuk alat komunikasi namun belum memanfaatkan alat tersebut sebagai alat bantu dalam membuat laporan keuangan. Sehingga perlu pengembangan aplikasi yang mudah dioperasikan dan dijalankan, namun dapat menghasilkan laporan keuangan yang sesuai kebutuhan dan tidak menyalahi standar.

Berdasarkan berbagai permasalahan di atas peneliti hendak membuat sebuah pnelitian yang berjudul "Pengembangan Aplikasi "Mikuro" Berbasis Android Sebagai Media Penyusunan Laporan Keuangan untuk Usaha Jasa". Penelitian ini bertujuan agar pemanfaatan smartphone lebih optimal. Selain itu, penelitian ini diharapkan dapat membantu para pelaku UMKM dalam pembuatan laporan keuangan. 


\section{JURNAL NOMINAL / VOLUME VII NOMOR 2 / TAHUN 2018}

\section{METODE PENELITIAN}

\section{Jenis Penelitian}

Penelitian ini merupakan penelitian riset dan pengembangan atau research and development $(\mathrm{R} \& \mathrm{D})$. Menurut Sukmadinata (2013: 164), "Research and development (R\&D) adalah suatu proses atau langkahlangkah untuk mengembangkan suatu produk baru atau menyempurnakan produk yang telah ada, yang dapat dipertanggungjawabkan", Penelitian ini bertujuan untuk mengembangkan aplikasi pembuatan laporan keuangan berbasis android.

\section{Tempat dan Waktu Penelitian}

Penelitian ini dilakukan di Universitas Negeri Yogyakarta dan di wilayah Yogyakarta. Adapun waktu pelaksanaan penelitian ini mulai dilaksanakan pada bulan Oktober 2017 sampai dengan bulan April 2018.

\section{Subjek dan Objek Penelitian}

Subjek dalam penelitian ini adalah 45 pelaku usaha mikro dan 4 validator yang terdiri dari 2 ahli materi dan 2 ahli media. Sampel untuk penilaian kelayakan produk sebanyak 45 pelaku usaha. Objek pada penelitian ini adalah aplikasi berbasisandroid untuk penyusunan laporan keuangan usaha mikro jasa.

\section{Prosedur Penelitian}

Prosedur penelitian yang digunakan dalam penelitian ini menggunakan model pengembangan 4D. Model penelitian ini menggunakan 4 tahap pengembangan yaitu
Define (analisis), Design (perancangan), Develop (pengembangan), dan Disseminate (penyebaran).

1. Tahap Define (Pendefinisian)

Dalam tahap ini peneliti menetapkan masalah mendasar yang dihadapi pengusaha dalam membuat laporan keuangan. Terdapat 2 analisis yang dilakukan dalam tahap ini, antara lain analisis ujung depan (kebutuhan), dan Analisis pelaku usaha. Tahap ini dilakukan untuk menganalisis kebutuhan terkait dengan media yang akan dikembangkan dengan cara mengkaji dari aspek pelaku usaha. Tahap pendefinisian ini juga dilakukan penernerjemahan aturan-aturan SAK EMKM yang akan di masukan dalam sistem pengoperasian aplikasi. Namun, tidak semua peraturan dalam SAK EMKM digunakan, karena terlalu rumit dan ada beberapa yang tidak terlalu dibutuhkan oleh pelaku usaha, misalnya catatan laporan keuangan. Aplikasi yang dikembangkan tidak memuat cacatan atas laporan keuangan, karena sistem akan terlalu rumit dan bagi pengusaha pemula belum terlalu membutuhkan laporan tersebut.

2. Design (Desain)

Tahap ini bertujuan untuk mendesain prototype media. Pada tahap ini dilakukan perancangan Aplikasi "Mikuro" sebagai media penyusunan 


\section{JURNAL NOMINAL / VOLUME VII NOMOR 2 / TAHUN 2018}

laporan keuangan. Tahap ini terdiri dari tiga tahap, yaitu:

a. Pemilihan media

Pemilihan media dilakukan untuk menentukan media yang tepat dalam penyajian materi dan penyusunan laporan keuangan. Aplikasi yang dipilih adalah android setelah mempertimbangkan beberapa hal. Proses pemilihan media disesuaikan dengan analisis kebutuhan, analisis pelaku usaha, analisis konsep, dan tujuan pengembangan.

b. Pemilihan format

Pemilihan format dilakukan dengan memilih format yang ada pada Android Studio yang selanjutnya dikemas menjadi media penyusunan laporan keuangan untuk usaha mikro. Pemilihan format ini disesuaikan dengan subjek penelitian yaitu, pelaku UMKM.

c. Rencana Awal

Rencana awal atau desain awal ini merupakan hasil awal rancangan produk yang akan dikembangkan. Pembuatan flowchart, desain media atau story board yang meliputi rancangan antarmuka yang akan tampil dalam aplikasi sehingga dapat memudahkan dalam melakukan pengembangan. Rencana awal juga meliputi penyusunan materi yang akan dimuat dalam aplikasi.
3. Develop (Pengembangan)

a. Pembuatan Media

Pembuatan media menggunakan Android Studio sesuai dengan pemilihan format yang telah ditentukan. Seluruh komponen yang telah dipersiapkan pada tahap desain dirangkai menjadi satu kesatuan media yang utuh sesuai dengan desain yang telah dirancang.

b. Penilaian Ahli.

Validasi, pada tahap ini divalidasi oleh dua ahli media dan dua ahli materi. Hasilnya berupa saran, komentar, dan masukan yang dapat digunakan sebagai dasar untuk melakukan revisi terhadap pengembangan. Pada tahap ini aplikasi yang dikembangkan direvisi berdasarkan masukan dan saran yang diberikan oleh ahli materi dan ahli media.

c. Uji pengembangan

Sebelum Aplikasi "Mikuro" ini disebarluaskan maka perlu adanya uji pengembangan. Tahapan ini sebagai tidak lanjut dari penilaian para ahli terhadap produk yang dikembangkan dalam skala kecil. Hasil dari uji coba ini merupakan represntasi kelayakan dan keberterimaan produk yang dikembangkan.

\section{Disseminate (penyebaran)}

Uji coba lapangan, pada tahap ini diujicobakan oleh pelaku UMKM. Pada 


\section{JURNAL NOMINAL / VOLUME VII NOMOR 2 / TAHUN 2018}

tahap ini juga dibagikan angket untuk mengetahui penilaian pelaku usaha mengenai media yang telah dikembangkan.

a. Apabila diperlukan maka akan dilakukan revisi berdasarkan masukan dan saran dari pelaku usaha. Namun dalam revisi ini akan mempertimbangkan masukan dan saran dari validator sebelumnya agar tidak bertentangan dengan perbaikanperbaikan sebelumnya.

b. Analisis data yang diperoleh untuk mengetahui penilaian mengenai media yang dikembangkan.

Data, Intrumen, dan Teknik Pengumpulan

Data

Instrumen pengumpulan data yang akan digunakan dalam penelitian ini adalah kuisioner. Kuesioner dalam penelitian ini digunakan untuk mengumpulkan data guna mengukur kelayakan aplikasi yang akan diberikan kepada ahli media, dan ahli materi sebagai bahan evaluasi aplikasi yang dikembangkan.

\section{Teknik Analisis Data}

Data yang telah dikumpulkan akan dianalisis untuk mengetahui penilaian dari produk yang telah dikembangkan.

a. Mengubah penilaian kualitatif menjadi kuantitatif dengan ketentuan. b. Menghitung nilai rerata skor tiap indikator dengan rumus.

$$
\bar{X}=\frac{\sum x}{n}
$$

$$
\begin{array}{ll}
\sum x & : \text { Jumlah Skor } \\
n & : \text { Jumlah subjek uji coba } \\
\bar{X} & : \text { skor rata-rata }
\end{array}
$$

Tabel 1. Pedoman Konversi Data Kuantitatif Menjadi Data Kualitatif

\begin{tabular}{llll}
\hline Skor & Interval skor & Nilai & Kategori \\
\hline $\mathbf{5}$ & $\mathrm{X}>4,2$ & $\mathrm{~A}$ & $\begin{array}{l}\text { Sangat } \\
\text { Layak }\end{array}$ \\
\hline $\mathbf{4}$ & $3,4<\mathrm{X} \leq 4,2$ & $\mathrm{~B}$ & Layak \\
\hline $\mathbf{3}$ & $2,6<\mathrm{X} \leq 3,4$ & $\mathrm{C}$ & Cukup \\
\hline $\mathbf{2}$ & $1,8<\mathrm{X} \leq 2,6$ & $\mathrm{D}$ & $\begin{array}{l}\text { Kurang } \\
\text { Layak }\end{array}$ \\
& & & Sangat \\
$\mathbf{1}$ & $\mathrm{X} \leq 1,8$ & E & \\
& & & Larang \\
& & & \\
\hline
\end{tabular}

HASIL PENELITIAN DAN PEMBAHASAN

\section{Tahap Define (Pendefinisian)}

a. Analisis Pelaku Usaha

Berdasarkan survei yang dilakukan oleh Srikandi dan Setyawan (2009) di lima kabupaten yang tersebar di wilayah Yogyakarta, dengan responden sebanyak 100 UMKM, dihasilkan kesimpulan bahwa sebagian besar UMKM masih jauh dalam menerapkan kaidah-kaidah akuntansi melalui siklus akuntansi, dan jenis usaha manufaktur lebih baik dibanding usaha barang dan jasa. Hasil penelitian menunjukkan bahwa pengelolaan 


\section{JURNAL NOMINAL / VOLUME VII NOMOR 2 / TAHUN 2018}

keuangan pada UKM di Yogyakarta masih jauh dari kaidah dan siklus akuntansi. Dari hasil skor tetimbang sebesar 0.42 (moderately weak association) pada skala Guttman diketahui bahwa penerapan siklus akuntansi di UKM Yogyakarta masih kurang. Pengelolaan keuangan para pelaku UKM hanya sampai pada tahap pencatatan transaksi sebesar $46 \%$ dan sebesar $67 \%$ yang memiliki bukti transaksi pada setiap transaksi usahanya dan hanya $45 \%$ yang melakukan perhitungan transaksi setiap bulannya. Jenis usaha yang lebih baik menerapkan kaidah siklus akuntansi adalah usaha manufaktur sebesar 35\%, karena dari segi pencatatan usaha manufaktur mencapai $22 \%$ dibanding usaha barang sebesar $16 \%$ dan jasa $8 \%$.

b. Analisis Pelaku Usaha

Analisis pelaku usaha diperlukan karena media harus sesuai dengan sasaran pengguna yaitu pelaku usaha mikro jasa. Berdasarkan penelitian yang dilakukan oleh Srikandi dan Setyawan (2009), apabila ditinjau dari tingkat pendidikan, maka dapat diketahui bahwa rata-rata pendidikan pengelola UMKM yang menjadi responden adalah SMU sebesar 48 orang (48\%), dan responden yang berpendidikan sampai SLTP sebanyak 25 orang (25\%), sedangkan yang berpendidikan sampai SD adalah 19 orang (19\%) dan hanya terdapat 8 orang $(8 \%)$ responden yang berpendidikan Sarjana. Dengan latar pendidikan yang SMA ke atas, pelaku usaha dapat mudah memahami materi yang tersedia di dalam Aplikasi "Mikuro" tersebut. Saat ini pun sudah banyak pelaku UMKM menggunakan smartphone dalam kesehariannya.

\section{Tahap Design (perancangan)}

Berdasarkan analisis kebutuhan perusahaan jasa yang menerapkan kaidah-kaidah siklus akuntansi hanya $8 \%$, maka pengembangan aplikasi "Mikuro" ini dikhususkan untuk jenis usaha jasa. Aplikasi "Mikuro" akan dilengkapi materi tentang perusahaan jasa. "Mikuro" merupakan media penyusunan laporan keuangan perusahaan jasa berbasis android. Pemilihan format tampilan media penyusunan laporan keuangan berbasis android dibuat sebagai berikut: Terdapat nama aplikasi pada tampilan awal atau spleshcreen, terdapat kolom untuk mengisis data-data perusahaan saat pertama kali menginstal aplikasi, terdiri dari tombol Jurnal, Laporan, Materi, Pengaturan, Petunjuk dan informasi tentang tim pengembang, materi yang ditampilkan di layar android dapat di scroll ke bawah maupun ke atas, icon gambar yang digunakan berkaitan tampilan menu 


\section{JURNAL NOMINAL / VOLUME VII NOMOR 2 / TAHUN 2018}

yang ditampilkan, gambar dibuat berwarna. Pembuatan Flowchart untuk menunjukan langkah-langkah prosedur atau program untuk memudahkan dalam proses pengembangan media. Pembuatan desain media (storyboard) untuk menggambarkan secara keseluruhan komponen apa saja yang ada pada tampilan layar. Materi yang disajikan dalam media dibuat format html (hyper text markup language) menggunakan program Notepad++.

\section{Tahap Develop (Pengembangan)}

\section{a. Pembuatan Media penyusunan}

\section{laporan keuangan Aplikasi}

"Mikuro".

Pada tahap pembuatan media terdapat 4 kegiatan yaitu pembuatan antarmuka, pengkodean (coding), pengujian (testing), dan deploying.

1) Pembuatan antarmuka

Antarmuka dibuat menggunakan aplikasi Andorid studio. Membuat antarmuka secara visual dalam android studio dapat dilakukan dengan dua cara yaitu drag and drop komponen yang sudah disediakan dan yang kedua adalah dengan coding yaitu dengan menuliskan serangkaian kode program sehingga membentuk tampilan program yang diinginkan.

Gambar 1. (a) Logo dan (b)Tampilan Awal/Splash Screen

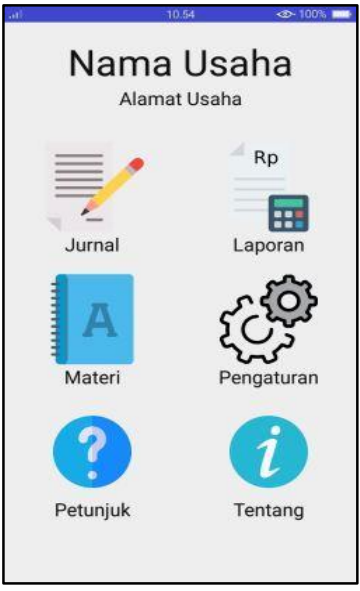

Gambar 2. Tampilan Menu Utama

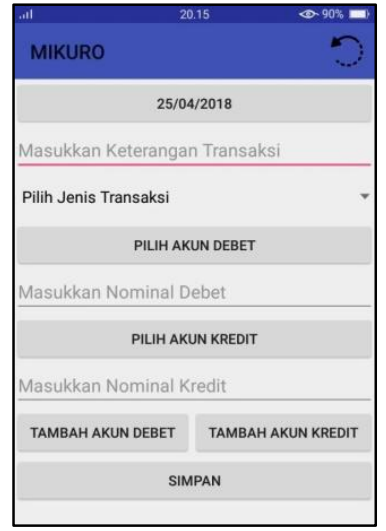

Gambar 3. Tampilan Saat Memasukan Transaksi dalam Jurnal 
JURNAL NOMINAL / VOLUME VII NOMOR 2 / TAHUN 2018

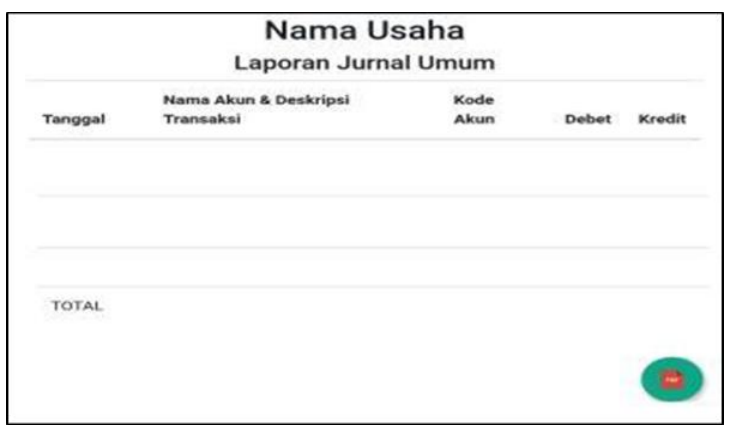

Gambar 4. Tampilan Laporan Jurnal Umum

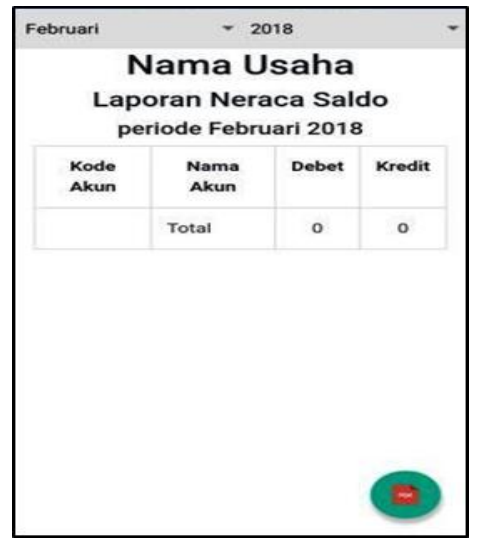

Gambar 5. Tampilan Neraca Saldo

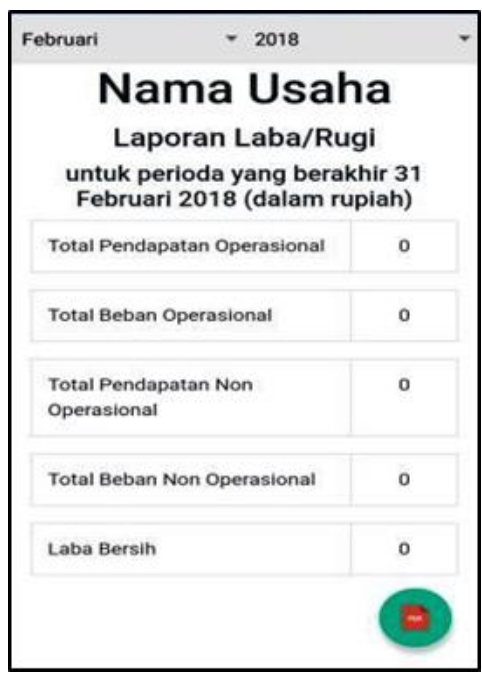

Gambar 6. Tampilan Laporan Laba Rugi

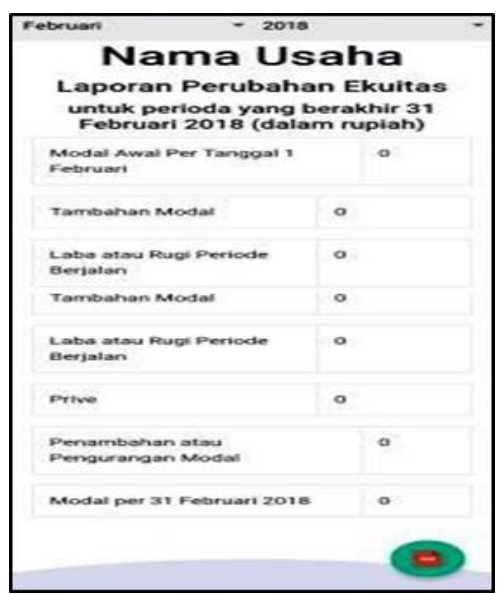

Gambar 7. Tampilan Laporan Perubahan Ekuitas

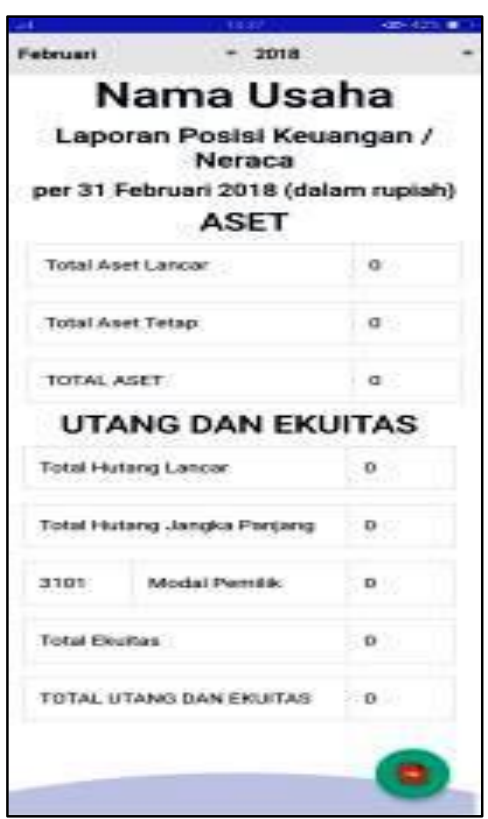

Gambar 8. Tampilan Laporan Posisi Keuangan/Neraca

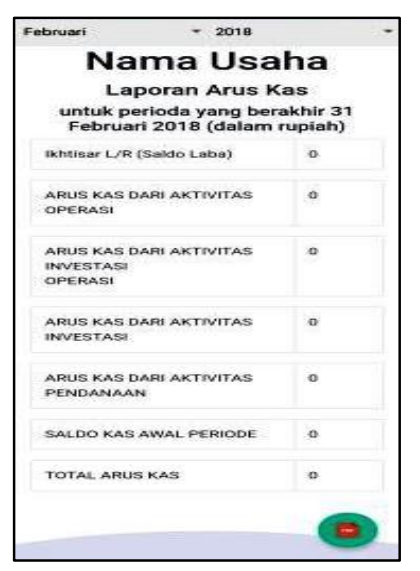

Gambar 9. Tampilan Arus Kas 


\section{JURNAL NOMINAL / VOLUME VII NOMOR 2 / TAHUN 2018}

2) Pengkodean (coding)

Pengkodean merupakan proses penerjemahan desain/rancangan aplikasi baik antarmuka maupun fungsi-fungsi yang ada di dalamnya ke dalam bahasa pemrograman untuk selanjutnya disatukan agar menjadi sebuah media yang dapat digunakan seperti yang telah direncanakan sebelumnya.

3) Pengujian (testing)

Pengujian dilakukan untuk mengetahui apakah fungsi-fungsi yang terdapat dalam aplikasi setelah proses coding dapat berjalan dengan benar dan menentukan kekurangan atau kesalahan yang harus diperbaiki, apabila dalam pengujian belum sesuai dengan yang diharapkan dan masih terdapat kesalahan maka akan dilakukan perbaikan hingga memperoleh hasil yang diharapkan.

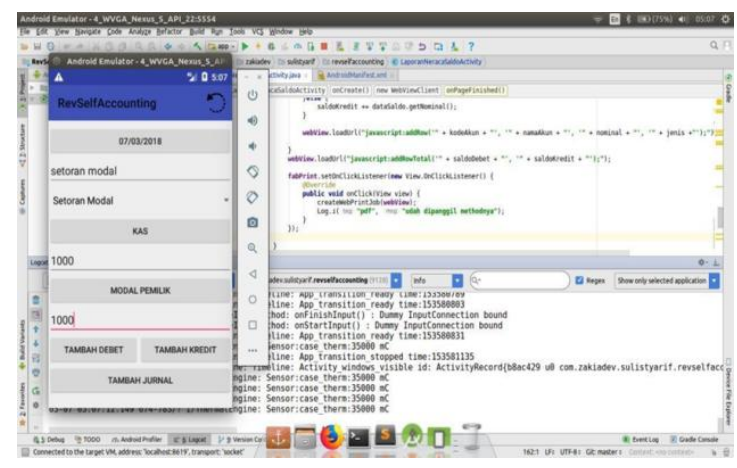

Gambar 10. Testing

4) Deploying

Deploying merupakan proses pentransferan Android Package (.apk) ke smartphone untuk proses implementasi. File tersebut dipindahkan ke smartphone melalui kabel USB untuk diinstal secara offline. File tersebut untuk selanjutnya juga dapat diunggah di Play Store sehingga dapat di download dan diinstal secara offline.

\section{b. Tahap Validasi}

Berikut hasil validasi dari masingmasing validator:

Tabel 2. Hasil Validasi Ahli Materi I

\begin{tabular}{|c|c|c|c|c|}
\hline No & Aspek & $\begin{array}{c}\text { Jumlah } \\
\text { Nilai }\end{array}$ & $\begin{array}{c}\text { Rata- } \\
\text { rata } \\
\text { Nilai }\end{array}$ & Kategori \\
\hline 1 & Materi & 28 & 4,67 & $\begin{array}{l}\text { Sangat } \\
\text { Layak }\end{array}$ \\
\hline 2 & Bahasa & 20 & 5 & $\begin{array}{l}\text { Sangat } \\
\text { Layak }\end{array}$ \\
\hline 3 & Keterlaksanaan & 28 & 4,67 & $\begin{array}{l}\text { Sangat } \\
\text { Layak }\end{array}$ \\
\hline & Total & 76 & 4,78 & $\begin{array}{l}\text { Sangat } \\
\text { Layak }\end{array}$ \\
\hline
\end{tabular}

Tabel 3. Hasil Validasi Ahli Materi II

\begin{tabular}{clccc}
\hline No & Aspek & $\begin{array}{c}\text { Jumlah } \\
\text { Nilai }\end{array}$ & $\begin{array}{c}\text { Rata- } \\
\text { Rata } \\
\text { Nilai }\end{array}$ & Kategori \\
& & & 4 & Layak \\
\hline $\mathbf{1}$ & Materi & 24 & 4 & Layak \\
\hline $\mathbf{2}$ & Bahasa & 16 & 4 & Layak \\
\hline $\mathbf{3}$ & Keterlaksanaan & 24 & 4 & Layak \\
\hline & Total & 64 & 4 & \\
\hline
\end{tabular}

Tabel 4. Hasil Validasi Ahli Media I

\begin{tabular}{ccccc}
\hline No & Aspek & $\begin{array}{c}\text { Jumlah } \\
\text { Nilai }\end{array}$ & $\begin{array}{c}\text { Rata- } \\
\text { rata } \\
\text { Nilai }\end{array}$ & Kategori \\
& & & 4,64 & $\begin{array}{c}\text { Sangat } \\
\text { Layak }\end{array}$ \\
\hline $\mathbf{1}$ & $\begin{array}{l}\text { Rekayasa } \\
\text { Perangkat }\end{array}$ & 51 & & \\
& Lunak & & & \\
& & & & \\
\hline
\end{tabular}


JURNAL NOMINAL / VOLUME VII NOMOR 2 / TAHUN 2018

\begin{tabular}{llccc}
\hline 2 & $\begin{array}{l}\text { Komunikasi } \\
\text { Visual }\end{array}$ & 37 & 4,11 & Layak \\
\hline Total & 88 & 4,37 & $\begin{array}{l}\text { Sangat } \\
\text { Layak }\end{array}$
\end{tabular}

Tabel 5. Hasil Validasi Ahli Media II

\begin{tabular}{|c|c|c|c|c|}
\hline No & Aspek & $\begin{array}{c}\text { Jumlah } \\
\text { Nilai }\end{array}$ & $\begin{array}{l}\text { Rata- } \\
\text { rata } \\
\text { Nilai }\end{array}$ & Kategori \\
\hline 1 & $\begin{array}{l}\text { Rekayasa } \\
\text { Perangkat } \\
\text { Lunak }\end{array}$ & 49 & 4,45 & $\begin{array}{l}\text { Sangat } \\
\text { Layak }\end{array}$ \\
\hline 2 & $\begin{array}{l}\text { Komunikasi } \\
\text { Visual }\end{array}$ & 40 & 4,44 & Layak \\
\hline & Total & 89 & 4,45 & $\begin{array}{l}\text { Sangat } \\
\text { Layak }\end{array}$ \\
\hline
\end{tabular}

\section{c. Uji pengembangan}

Sebelum media diuji langsung pada pengguna media ini diujikan pada 10 Pelaku UMKM wilayah kota Yogyakarta. Tujuan dari dilakukannya uji pengembangan ini adalah untuk mengetahui respon pelaku UMKM terehadap "Mikuro" sebagai media penyusunan laporan keuangan.

Tabel 6. Hasil Uji Pengembangan

\begin{tabular}{|c|c|c|c|c|}
\hline $\begin{array}{l}\mathbf{N} \\
\mathbf{o}\end{array}$ & Aspek & $\begin{array}{c}\text { Jumlah } \\
\text { Skor }\end{array}$ & $\begin{array}{l}\text { Skor } \\
\text { Rata- } \\
\text { rata }\end{array}$ & Kategori \\
\hline 1 & $\begin{array}{l}\text { Rekayasa } \\
\text { Perangkat } \\
\text { Lunak }\end{array}$ & 230 & 3,83 & Layak \\
\hline 2 & Bahasa & 77 & 3.85 & Layak \\
\hline 3 & $\begin{array}{l}\text { Komunikasi } \\
\text { Visual }\end{array}$ & 347 & 3,86 & Layak \\
\hline & Rata-rata & 654 & 3,85 & Layak \\
\hline
\end{tabular}

\section{Disseminate (Penyebaran)}

Penyebaran media dilakukan dengan cara mengirimkan alamat Google Drive dimana aplikasi "Mikuro" dapat diunduh oleh masing-masing pelaku usaha. Setelah menggunakan aplikasi "Mikuro", pelaku usaha diminta respon atau pendapatnya dengan mengisi angket yang telah diberikan. Berikut ini rekapitulasi hasil rata-rata penilaian dari 35 pelaku usaha.

Tabel 7.Hasil Penilaian dari Pelaku Usaha

\begin{tabular}{llccc}
\hline No & Aspek & Jumlah & Skor & Kategori \\
& & Skor & Rata- & \\
& & & rata & \\
\hline $\mathbf{1}$ & Rekayasa & 800 & 3,81 & Layak \\
& Perangkat & & & \\
& Lunak & & & \\
\hline $\mathbf{2}$ & Bahasa & 265 & 3,79 & Layak \\
& & & & \\
\hline $\mathbf{3}$ & Komunikasi & 1.254 & 3,98 & Layak \\
& Visual & & & \\
\hline & Rata-rata & 2.319 & 3,86 & Layak \\
\hline
\end{tabular}

Pengembangan "Mikuro" sebagai media penyusunan laporan keuangan dikembangaka menggunakan model Four$D$ yang dikembangkan oleh Thiagrajan, dan Semmel pada tahun 1974. Penelitian pengembangan ini dilakukan melalui empat tahap yaitu, pendefinisian (define), perancangan (design), pengembangan (develop), dan penyebaran (disseminate). Pertimbangan penggunaan model ini adalah model Four-D terstuktur secara sistematis serta sesuai dengan rencana pengembangan media yakni sampai pada tahap penyebaran. 


\section{JURNAL NOMINAL / VOLUME VII NOMOR 2 / TAHUN 2018}

Penilaian kelayakan "Mikuro" pada tiap tahap tersebut apabila ditampilkan dalam diagram batang dapat dilihat pada gambar di bawah ini:

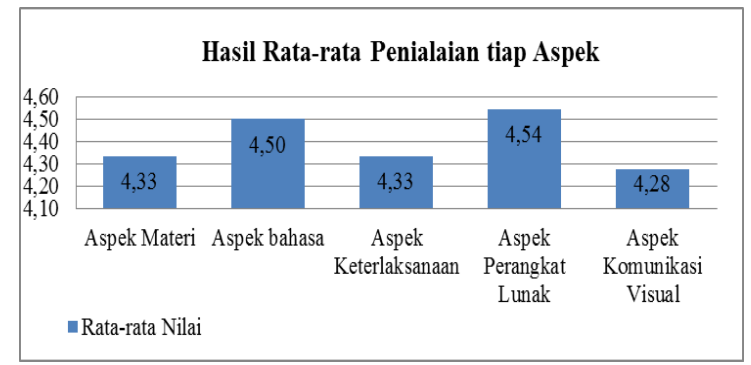

Gambar 11. Diagram Batang Kelayakan

"Mikuro" pada Tahap Validasi.

Aspek perangkat lunak mendapat nilai tertinggi dari pada aspek-aspek yang lain. Hal tersebut dapat diartikan bahwa Mikuro merupakan aplikasi yang reliabel, handal, mudah untuk digunakan. Hal tersebut dapat diartikan bahwa Mikuro merupakan aplikasi yang reliabel, handal, mudah untuk digunakan. Menurut Institut Teknologi Telkom (2017), "Pada perangkat lunak yang terkait keperluan bisnis, usability dan maintainability adalah faktor utama yang dipertimbangkan. Perlu diingat bahwa dalam Rekayasa Perangkat Lunak, kualitas perangkat lunak adalah segalanya". Setelah mendapat penilaian dari para ahli (Ahli Materi dan Ahli Media) maka produk yang dihasilkan siap digunakan di lapangan.

Aplikasi "Mikuro" berbasis android dengan demikian layak digunakan sebagai media penyusunan laporan keuangan. Sesuai dengan pendapat Eko P. Widoyoko (2013: 112) menyatakan suatu produk dikatakan layak apabila memperoleh nilai minimal B atau dalam kategori layak.

Aplikasi "Mikuro" ini merupakan media untuk menyusun laporan keuangan perusahaan jasa. "Mikuro" dapat memproses data transaksi yang dimasukan oleh pengguna menjadi sebuah laporan keuangan yang berupa, Jurnal Umum, Neraca Saldo, Laporan Laba/Rugi, Laporan Perubahan Ekuitas, Laporan Posisi Keuangan/Neraca, dan Laporan Arus Kas. Aplikasi "Mikuro" disajikan dalam tampilan dengan didominasi warna putih sebagai warna utama, warna biru muda dan jingga pada tampilan materi. Aplikasi "Mikuro" memeliki beberapa kelebihan dan kekurangan sebagai media penyusunan laporan keuangan. Kelebihan media ini antara lain:

a. Aplikasi "Mikuro" dapat digunakan dimana saja dan kapan saja.

b. Aplikasi "Mikuro" juga dapat digunakan sebagai sarana belajar akuntansi perusahaan jasa karena dilengkapi menu materi di dalamnya.

c. Aplikasi "Mikuro" dapat memproses data transaksi menjadi jurnal umum dan laporan keuangan.

d. Aplikasi "Mikuro" dapat membackup data sehingga data-data yang telah dimasukan dapat tersimpan dengan aman dan dapat dikirimkan kepengguna lain.

e. Laporan keuangan yang dihasilkan dapat diubah menjadi file PDF 


\section{JURNAL NOMINAL / VOLUME VII NOMOR 2 / TAHUN 2018}

sehingga dapat dicetak menjadi hard file.

Kekurangan media ini antara lain:

a. Pengguna aplikasi "Mikuro" terbatas pada perusahaan jasa.

b. Tampilan aplikasi "Mikuro" sangat bergantung pada spesifikasi jenis smartphone pengguna.

c. Kemudahan penggunaan aplikasi "Mikuro" sangat bergantung pada keahlian pengguna.

d. Aplikasi "Mikuro" tidak terdapat memberikan peringatan apabila pengguna salah memasukan akun-akun dalam jurnal.

Aplikasi "Mikuro" yang diinstal di smartphone pelaku usaha dapat dimanfaatkan dalam mendukung aktivitas bisnisnya. Penelitian yang dilakukan Chen dkk (2009), menyoroti tentang efetivitas penggunaan smartphone pada perusahaan penyedia jasa, bahwa penggunaan smartphone akan efektif dalam aktivitas bisnis. Selain dapat membantu dalam menyusun laporan keuangan "Mikuro" juga dapat dijadikan sarana belajar para pengguna tentang akuntansi perusahaan jasa dengan materi penyusunan laporan keuangan. Menurut Mushrain (2016), "Pemanfaatan Android saat ini berfokus tidak hanya sebagai instrumen atau sarana komunikasi atau hiburan tetapi juga sebagai sumber pembelajaran dan media". "Mikuro" dapat dimanfaatkan sebagai mobile learning, pengguna dapat mempelajari materi yang dikemas secara praktis dalam satu aplikasi. Manfaat mobile learning, seperti yang dinyatakan oleh Kyun Baek dan Uk Cheong (2005) adalah kemungkinan penerapan lingkungan belajar di mana-mana, kemungkinan pembelajaran seumur hidup dan kemungkinan pendidikan melalui hiburan "edutainment". Dengan adanya pengembangan M-learning, seseorang akan dapat belajar di mana saja kapan saja. Ponsel yang dikenal sebagai mobile learning akan membuat proses belajar lebih fleksibel sehingga tidak harus menghadiri tempat khusus untuk menjalani proses pembelajaran. G Stead (2005) menyatakan "The evolution of learning paradigm from traditional classroom based learning and learning electronic had brought out the new learning paradigm based on mobiles which is known as Mlearning". Belajar dengan menggunakan ponsel akan lebih efektif dan efisien.

\section{PENUTUP}

\section{Kesimpulan}

Berdasarkan hasil penelitian maka dapat diambil kesimpulan sebagai berikut:

a) Pengembangan aplikasi "Mikuro" berbasais android sebagai media penyusunan laporan keuangan dikembangkan dengan model Four D yang dilakukan melalui tahap Define, Design, Develop, dan Disseminate. 
JURNAL NOMINAL / VOLUME VII NOMOR 2 / TAHUN 2018

b) Penilaian dari ahli materi tentang kelayakan "Mikuro" sebagai media penyusunan laporan keuangan, memperoleh nilai rata-rata dari ahli materi I, sebesar 4,78 dengan kategori sangat layak, sedangkan dari ahli materi II memperoleh nilai rata-rata 4,00 dengan kategori layak, sehingga jika dirata-rata penilaian dari ahli materi memperoleh skor 4,39 yang dikategorikan "Sangat Layak".

c) Penilaian dari ahli media tentang kelayakan "Mikuro" sebagai media penyusunan laporan keuangan, memperoleh nilai rata-rata dari ahli media I, sebesar 4,37 dengan kategori sangat layak, sedangkan dari ahli media II memperoleh nilai rata-rata 4,45 dengan kategori sangat layak, sehingga jika diratarata penilaian dari ahli media memperoleh skor 4,41 yang dikategorikan "Sangat Layak".

d) Penilaian dari pelaku usaha mengenai aplikasi "Mikuro" menunjukan skor rata-rata 3,86 yang dapat dikategorikan "Layak".

\section{Saran}

Pelaku usaha jasa disarankan agar dapat memanfaatkan aplikasi "Mikuro" ini untuk menyusun keuangan. Pelaku usaha juga dapat belajar cara menyusun laporan keuangan melalui aplikasi "Mikuro".

Aplikasi ini perlu disempurnakan lebih lanjut agar cara pengoperasiannya lebih sederhana, sehingga dapat mempermudah pelaku usaha yang masih tergolong pemula. Hal ini sesuai dengan masukan dari pelaku usaha.

Peneliti juga menyarankan adanya pada pengembangan selanjutnya agar "Mikuro" tidak hanya menghasilkan laporan keuangan saja namun juga dapat menghasilkan laporan kinerja keuangan.

\section{DAFTAR PUSTAKA}

Badan Pusat Statistik (BPS). (2016). Hasil Sensus Ekonomi 2016. Diakses tanggal 8 Oktober 2017dari http://se2016.bps.go.id.

B. Young-Kyun and C. Dong-Uk, (2005). "Present and Future Prospects for Mobile Learning in Korea", Proceedings of the 2005 IEEE International Workshop on WMTE

Hanafi, dan Halim. (2014). Analisis Laporan Keuangan Edisi Tujuh. Yogyakarta: UPP AMP YKPN.

G. Stead (2005). "Moving Mobile into the Mainstream", 4th World Conference of M- Learning.

Institut Teknologi Telkom, (2017). Karakteristik Software Berkualitas. Diakses tanggal 14 Mei 2018 dari http://rpl.st3telkom.ac.id/karakterist ik-software-berkualitas/

Jengchung V. Chen, David C. Yen, dan Kuanchin Chen. (2009). The acceptance and diffusion of the 
innovative smart phone use: A case study of a delivery service company in logistics. Jurnal Information and Management. Vol. 46 No.4 Hal: 241-248.

Mushrain. (2016). Developing AndroidBased Mobile Learning as a Media in Teaching English. Prosiding International Conference On Teacher Training and Education Sebelas Maret University. Vol. 2 No.1 Hal: 307-313.

Raharjaputra, H.S. (2011). Manajemen Keuangan dan Akuntansi. Jakrta: Salemba Empat.

Setyorini, Dhyah, dkk. (2002). Pelatihan Akuntansi UMKM bagi Usaha Mikro Kecil Menengah (UMKM) untuk Meningkatkan Kinerja Keuangan Perusahaan. Diakses dari http://staffnew.uny.ac.id pada tanggal 21 November 2017.

Srikandi, Cut \& Setyawan, Aris Budi. (2009). Analisis Penerapan Siklus Akuntansi pada Usaha Kecil dan Menengah di Daerah Istimewa Yogyakarta. Skripsi. STIE Mega Nusa kencana.

Sukmadinata, N.S. (2013). Metode Penelitian Pendidikan. Bandung: Pt Ramaja Rosdakarya Offset.

UMKM Belum Mampu Susun Laporan Keuangan. Diakses tanggal 28 Oktober 2017 dari http://jogja.tribunnews.com/2017/1 0/25/80-umkm-belum-mampususun-laporan-keuangan

Widoyoko, E.P. (2014). Teknik Penyusunan Instrumen Penelitian. Yogyakarta: Pustaka Pelajar. 